\title{
The German and Bluntschli Influence on the Establishment of Public Administration
}

\author{
Ali Rıza Sakli \\ Department of Public Administration, Faculty of Economics and Administrative Sciences, \\ Recep Tayyip Erdogan University
}

Fener Mah. Zihni Derin Kampus 53100 Rize, Turkey

Tel: +90.464.2235864/1166 E-mail: alirizasakli@yahoo.com

Received: March 13, 2013 Accepted: March 28, 2013 DOI: 10.5296/jpag.v3i1.3441

\begin{abstract}
The emergence of the discipline of public administration had long been attributed to Wilson. Martin (1987 and 1988) manifested that the discipline originated in France and consequently passed to USA. However, Wilson's 1887 article "The Study of Administration" points to the fact that he based the administration-politics dichotomy on German Bluntschli. This showed that it was essential to analyze the German influence on and, in particular, Bluntschli's contribution to the birth of the discipline of public administration. The present study focuses on Seckendorf, Wolff, Hegel and Stein's theoretical contributions to the emergence of public administration in Europe and intends to investigate each of them with a particular emphasis on Bluntschli's influence. It has appeared that the politics-administration dichotomy, which had a great effect on Wilson, was prevalent in the works of Bluntschli, in which the term primary is used for politics to refer to the former and secondary for administration to refer to the latter. Although politics administration difference was expressed in the French literature of public administration, it was concluded that the German effect was significant in the emergence of public administration and its spread to USA.
\end{abstract}

Keywords: Emergence of public administration; German influence on public administration; Bluntschli; Wilson 


\section{Introduction}

When the emergence of public administration is defined as a disintegration process from politics and law and development into a discipline in itself, the German contribution to this process turns out to be the subject of this study.

Studies on the origins of the discipline of public administration are still being conducted although nearly a 150 year-period has passed since the date the politics-administration dichotomy was first established. One reason for this is that the academics have not focused much on the period when the discipline emerged. In particular, simply attributing the establishment of discipline to Wilson almost became a fashion in academic circles.

Subsequent essays began to appear in the literature, asserting that the famous politics-administration dichotomy, which is important for the independence of public administration from political science, does not belong to Wilson but to the French, the ancestors of the American public administration (Martin 1987). Accordingly, politics-administration dichotomy was coined by Vivien in 1859. Still, this issue had gaps because one thing that Wilson explicitly states in his well-known article "The Study of Administration" (1887) was untouched.

Wilson $(1887,210)$ stated that the politics-administration dichotomy belongs to the German authors, who were "distinguished authorities in the literature," and in particular to Bluntschli. It was deemed necessary to define the German influence on the emergence of public administration more comprehensibly since Wilson, who was accepted to be the founder of public administration by the academic circles of a certain era, made reference to German scholars and especially to Bluntschli and cited him as his main source.

As Johann Caspar Bluntschli was the most influential scholar for Wilson, his thoughts on state and public administration also needed to be analyzed. Although occasional references to Bluntschli exist in the literature of public administration, they are no more than narrow scoped mentions, which refrain from giving a more comprehensive account of his opinions related to the topic.

This essay traces the development trend of the emergence of public administration in Germany, where Cameralism-commonly accepted as the source of public administration- is believed to have originated and flourished. It covers the major writers' views concerning the state and public administration starting from the period before Cameralism up to Bluntschli. It also intends to analyze the extent to which Wilson was influenced by the German state theory and German approach to public administration and what implications this had on USA public administration.

\section{The Thoughts That Founded Public Administration in Germany}

The fact that Cameralism was born in Germany makes this country the most influential one in the emergence of public administration. This section presents an account of the emergence process of public administration in Germany and includes the views of major actors in the academic process that led to the emergence of the discipline. 


\subsection{Veit Ludwig von Seckendorff (1626-1692)}

The first specific work to deal with the themes of public administration was German Principality published by Seckendorff in 1656. In this book, Seckendorff, who discusses administrative issues on the level of a small principality, aimed to go beyond the daily problems and local applications (Rutgers 2010a, 7).

German Principality, described as the "user manual" of a small state, also covers history, population, economy, school systems, law and justice, as well as administrative science. Seckendorff, who regards the state as a holistic organism, holds the opinion that "common weal" can only be understood by this holism (Reinert 2005, 226). The holistic perception of the state naturally brought with itself the consideration of the state administration together with other areas related to the state.

Seckendorf puts forth the administration of the principality within the context of the prince's point of view, yet this does not mean the "strong prince" of Machiavell's Prince in any way whatsoever. Explaining the power of the prince, he also highlights that he has limited power. This is because of the limitations in the princedom, as well as the fact that the principalities function under the political system of the Holy Roman-German Empire (Klinger 2005, 253).

Then, it is possible to come across many elements that constitute the thought of "cameral sciences" in Seckendorff's works. Apart from these, he puts an emphasis on state administration, statesmanship, political science, and thus advocates unity in administration, politics and economy. On the other hand, he considers the state as an organism and proposes a "task" oriented system. Again, he attaches special importance to public education and awareness. There are traces of the early ideas related to the welfare state and mentions of government's responsibility to help the needy in his first works, which are accepted as the initial efforts to give prominence to public administration (Reinert 2005, 227-228).

The writer, who distances himself from religion and philosophy, describes his work German Principality as scientific, in which he intends to provide general knowledge on administration. His works do not bear much significance for the public administration implementations (Rutgers 2010b, 1-2).

As can be seen here, Seckendorff inspected the administration in German principalities in all aspects and also dealt with the subjects of economic welfare and education, as well as administrative problems. He took the state administration as one whole and the state as a living organism. These studies of Seckendorf concerning state administration contributed drastically to the development of Cameralist thoughts.

\subsection{Christian von Wolff (1679-1754)}

Wolff, who lived in a period when Cameralist scientific doctrines prevailed, contributed significantly to this approach. Wolff's Cameralist philosophy has such a principle that highlights public administration. According to Wolff, "common good" and "peace" are two important objectives of state administration. For this objective to be met, any administration should act protecting "justice" and "benefit". The approach pertaining justice and benefit is not merely a corporate entity; the administrators of a state have to be fair and determined to 
improve the "common good" (Rutgers 2010b, 9). "Benefit" acknowledged by Wolff is nothing else, but public benefit, which would later be referred to as "common welfare".

The first author to use the concept of eudaimonic state in relation with the development of the theory of the administration, Wolff interpreted public administration as the happiness for citizens and attempted at laying the philosophical foundation, thereof. Citing Wollf's role in relation with Cameralism from Marchet, Rutgers (2010b, 1-2) asserts that Wolff signifies a philosophical beginning and departure for Cameralism. Wolff's Philosophy of Cameralism has prioritized public administration.

Philosophy of Nature can be said to have been first developed by Wolff, who bases the central doctrine of Cameralism on his own sytem of natural law. Principles of Natural Law propounded by Wolff have assured Cameral Principles serve both dynasty and the country. Wolff's Principles of Natural Law are accepted as the antecedent of the principle of subsidiarity - local services must be governed by the lowest administrative level that is most immediate to the action - practised now in EU (Backhaus 2001, 20).

In Wolff's view, the state and the society are not two opposite poles; on the contrary, they are united. When the members of a family try to make one another happy, it creates a "common wealth". And the common wealth makes the state. According to him, just as human behaviours, the state hinges on the natural law. The foundation of a state is based on the contemporaries' ideas. If an individual seeks his freedom, the state takes care of its citizen and, as a state of welfare, guarantees his freedom and contentment. The government of the state that does not serve its purpose is bound to be critisized (Rutgers 2010b, 8).

Wolff, on the one hand, advocates the basis for a welfare guaranteed by the state; on the other hand, he is against a basis for a welfare automatically provided by the state to the citizens (Reinert 1999, 280). It is evident that guaranteeing the individuals' freedom is regarded to be a part of a system which necessitates making sacrifices and efforts.

According to Wolff, the state intervension should regulate three areas: public health, protection of the poor and charities. This, however, requires the establishment of a complex judiciary network structure (Rutgers 2010b, 9).

\subsection{Friedrich Hegel (1770-1831)}

The state system based on Hegel's idealist philosophy served to bring together and harmonize the regional administrative structures that had been detached from the central structure in Germany (Seibel 2010, 729). Hegel, who regards the state as the actuality of ethical idea and divine manifestation, advocates that the general will emerges in a tangible form in the state. There is full compliance between the general will in the state and the personal will. The unique and the superior state encompasses the individuals, too (Agbude 2011, 118).

The starting point of Hegel's state philosophy is freedom. Nevertheless, this freedom does not give prominence to individuality, but locate the individual within the society of which he is a member. Among the laws and customs of the society, to which he belongs, lies an individual's having freedom of thought and freedom of emotion (Hobhouse 1999, 22-23). Hegel's such understanding of freedom hinges on the idea that the individual's freedom can only be 
guaranteed under the protection of the government.

Hegel takes the state and the society as two separate and legal point of activity and asserts that the state must secure the existence, security and welfare of the individual. In particular, among the conflicting interests, it is the state's duty to protect the weak individuals and provide them with minimum standards of living (Rutgers 2010a, 17-18).

Hegel's concept of state predicts a systematic and a large scale combat against poverty, yet he does not find this sufficient as he also demands that the poor be allowed to benefit from political liberties and intellectual objectives of the modern society (Ferraro and Ajenjo 2007, 4). While a state can fulfil its responsibilities for the individual and the society only through public administration, Hegel does not go any further from this point. Thus, these opinions of Hegel concerning the state and the society have solely been included in the public administration analyses owing to the works of Lorenz von Stein (Rutgers 2010a, 18).

\subsection{Lorenz von Stein (1815-1890)}

The first theoretician to significantly conceptualize public administration, Stein sees the state as a living organism that acts in harmony. He regarded the state as a "working state" (arbeitender Staat), which helped to put forward the concept of public administration as the performance of the state affairs (Seibel 2010, 3-9).

Although Cameralism was taught at the universities in the author's time, it was mostly analyzed as the state administration of principalities. Stein, distinguished between the state administration and the administrator, considering it as an autonomous entity. By this way, state administration was dealt with separately from both the emperors governing the state and the arena of the conflicting interests defined by Hegel (Ferraro and Ajenjo 2007, 4).

In Stein's time, public administration was considered to be a part of administration law in Europe (Thornhill 2006, 794). Stein believed that it was much too restrictive and stated that public administration depends on a variety of disciplines including sociology, political science, public finance and administration law. He regarded public administration as a discipline and field of practice wherein all these disciplines are integrated (Lodhi and Mikulecky 2010, 105).

Stein's concept of state is obviously based on Hegel, yet advancing Hegel's opinions, he has made important conceptualizations for public administration. It is important that, among these, he divides the state into two constituents: "constitution" and "administration". $\mathrm{He}$ maintains that the political freedom of an individual, who has been given social security by the constitution, should also be protected by the "social state administration" in case of adverse developments. These opinions of Stein on public administration and social state led to considerable effects throughout the 19th century both in Europe and USA (Ferraro and Ajenjo 2007, 4-5).

Stein's major works are known both by Wilson and Goodnow and have been a major source of inspiration for them (Miewald 1984, 19). It could be claimed that the differentiation of constitution and administration is a starting point for the emergence of the constitutional democratic state. Supporting this and containing a clear reference to Stein, the discourse in 
Wilson's well-known article "The Study of Administration" is based on Stein's point of view (Ferraro and Ajenjo 2007, 5).

Stein, accepted by many researchers (Thornhill 2006, 794; Lodhi and Mikulecky 2010, 104; Thornhill and Dijk 2010, 99) as the founder of public administration in Europe, laid down the following ideas with a novel approach:

- The study of public administration is the melting pot of so many disciplines as sociology, political science, public finance.

-Public administration is an integrated science.

- Although public administration is a theory, an interaction should exist between theory and practice, but that practice had to form the base.

- Public administration should seek to develop a scientific method (Thornhill 2006, 794).

Stein advocates that a state administration has to utilize all human knowledge to serve the citizens' liberty and to achieve a better society, and for this reason, he considers public administration to be the crown of all sciences. Thus, Stein aimed to combine all sciences and achieve a large scale science of administration (Rutgers 2010a, 8-25).

\section{J.C. Bluntschli and the Discipline of Public Administration}

The organic state theory is the essence of Swiss born Bluntschli's (2000, 24-25) opinions concerning the state. To him, the state is not a dead machine or a lifeless tool. The state has an organic structure, yet the organic structure of the state, which had been overlooked by political scientists, was acknowledged by the German school of historical jurists. This viewpoint not only contradicts with the mathematical and mechanical account of the state but also rejects that it has an atomistic structure. Bluntschli points out that the atomistic approaches ignore the unity of individuals; the state is indirectly a human production, and that it is not a natural organism but a copy of those organisms.

According to Bluntschli (2000, 25), an organism has three main elements as (1) the formation of soul and body union, (2) though a whole, its possession of the pieces which constitute itself and (3) growing outwards. The writer thinks that all three are present in the state.

What lie in the center of Bluntschli's concept of organic state are the state's national spirit and its consideration as an organ aiming to fulfill the common will. The state is described as an arrangement between government, society and the individual (Rosser 2011, 1-7).

Bluntschli, who has produced several well-known studies in the field of law (2000, 64; 12-14), investigates the state through civil law-politics dichotomy, proposed by Machiavelli, and indicates that state is a combination of law and politics.

According to Bluntschli (2000: 405,406), Bodin is the first to state that the prince should not be involved in judgment and this activity should be carried out by independent tribunals. Montesquieu, however, is to predict the necessity of carrying out legislation, execution and judgment in separate units for civil freedom and security. 
Having made references to Bodin and Montesquieu's conceptualizations, Bluntschli (2000: 408) attempted at making the organic theory of the state compatible with separation of powers. He believes that just as different organs in the human body serve different purposes and different organs should perform different tasks. The author does not approve of naming this distinction as "separation of powers", contending that a right thing has been named wrong, for just as with the organs of a body, the unification of these organs is as important as their separation.

Bluntschli (2000, 411-412) believes that a state has four major organs. The most important two, which are at supreme positions, are (1) government (or administration) and (2) legislation power, whereas the other two are (3) protecting and preserving the intellectual elements of religion, science and the culture (containing the art) and (4) the political economy involving the protection and management of material benefits. Such civilization elements as religion, science and art are not directly connected to the state organism. The state's relation with the institutions of religion, science and art such as church and school like elements is drastically different from its relation with its own field. On the other hand, public finance, as the management of the state's income and expenditures, depends on technical knowledge and experience rather than the state authority, and it does not involve a rigid use of the sovereign power.

Bluntschli (2000, 409-410), who studies the execution function, or in his own words government and administration functions of the state, has the opinion that, whether it is one person who makes and executes a decision or gives orders and commands to others, decision making is "primary" and enforcement is "secondary". According to him, the function of the government is inherently primary; it makes decisions, plans, expresses it's will, commands or forbids, yet most of the time these orders are fulfilled noncompulsorily. If use of force is needed for the orders to be obeyed, the government will undoubtedly use so, but as it is a task which is of secondary nature, it has been entrusted to inferior officers like policemen."

It is clear in the writer's discourse that political decision making is defined as a primary duty and the execution of the decisions is defined as a secondary function. It can also be understood that the activity defined "secondary" as the implementation of civil practices is in fact public administration.

Bluntschli $(2000,410)$ refers to the general administration of the state as "politics" and the administration concerning the details as "administration". The very essence of the government is, in particular, to protect the country and the nation against external attacks and threats, represent them and to hold the power to command and order to defend the country from common enemies. The government has government and representation power at the supreme level.

The government function involves general and high level issues and is named as politics, whereas more detailed state practices call for public administration, in Bluntschli's primary-secondary dichotomy. It is evident that politics, which is closely related to decision making, has a primary function and public administration, which is closely related to the implementation, is described as the secondary function. 
According to Bluntschli (2000, 414-416), who focuses on the public-service function of the state, all primary and secondary services obliged by, or committed voluntarily for, the state are public services. The religious institutions and unions also do public service by serving the community, yet it is not a service connected to the state. All public services cannot be included in the framework of public functions and all who are doing public service are not public servants. He studies those who are doing state jobs in two categories: state employees and their assistants.

Bluntschli (2000, 417-421) studied the issue of assignment of civil servants to public service and stressed that the practice of passing on the state positions to others by means of legacy, which was common in the middle ages, is quite contrary to the modern understanding and that there might be other professional and honorary duties. He asserts that assignment to professional jobs, which he thinks is more crucial for the modern state, requires technical knowledge, training and candidacy procedures.

Bluntschli (2000, 422-426) examined the rights and responsibilities of civil servants. Having dwelt on such rights and responsibilities as fulfilling the duties related to the job description, obeying the orders, using the titles given and receiving the wages deserved, he puts emphasis on the subject of job discipline.

Bluntschli $(2000,427-430)$ also studied the end of the public service. He maintains that public service is not bound to individuals; the services should continue independently from individuals, owing to the continuity of the state. He exhibits that it is up to the individuals to be assigned to a duty or not or to resign from the job or not, but once they are assigned to a duty, they are responsible to fulfill its requirements and they cannot then neglect it.

Bluntschli, who touched on the politics - administration dichotomy, defined politics as primary and administration as secondary within the context of decision making and implementation, did not only focus on the concept of public services but also extensively covered such topics as the problems related to the fulfillment of public services. It is considered essential to tackle the administrative problems in implementation, deal with public servants' staffing, service and problems, and to accept that certain public services are provided by non-state organs.

It is seen that, in his book The Theory of the State $(2000,448,487,490)$ Bluntschli references the French scientist Vivien at four different points, which indicates that he has analyzed Vivien's 1852 article Administrative Studies (Eiudes Administrarives). Vivien established the politics - administration dichotomy, which makes it evident that, because the well known dichotomy was known to be put forth (Martin, 1987), Bluntschli was not the first to make this dichotomy. However, politics' expression as "primary" and administration's as "secondary" is ascribed to the writer.

\section{The German School That Fed Wilson}

The American political science and public administration had been profoundly influenced by German political theory by late $19^{\text {th }}$ Century. Back then, thousands of students were flocking to Germany to go to university for a few semesters there. Most of the Woodrow Wilson's professors at Johns Hopkins University had received education in Germany and were under 
the effect of the German political theory (Rosser 2010, 549).

Among them, Wilson was most immensely influenced by Richard T. Ely and Herbert Baxter Adams, both of whom had studied under Bluntschli at the Heidelberg University (Pestritto, 2005: 8). Obviously, Bluntschli, a state and politics theoretician loyal to Hegel's philosophy, played a substantial role in forming Wilson's opinions on public administration.

Having indicated that public administration is different from politics and constitutional study, Wilson $(1877,209-210)$ states that the "administration lies outside the proper sphere of politics" and "administrative questions are not politic questions". From here on, Wilson pronounces that the politics - administration dichotomy should be attributed to "eminent German writers", "high authorities" in the field, making a reference to Bluntschli's work Politik and asserting here that public administration should diverge from both politics and law.

The only book of Bluntschli which bears the name "Politik" is "Geschichte des algemeinen Staatsrechts und der Politik". However, Link $(1968,431)$ points to the fact that it is not this study that Wilson makes a reference to, but it is the third volume of the Bluntschli's major book The Theory of the State, which is "Politik als Wisselschaft" (Politics as Science). As it is the well-known book The Theory of the State, wherein Bluntschli discusses the subjects of state and public administration, Link's view seems to be right.

As Bluntschli contends in his book The Theory of the State $(2000,410)$, "the execution power" put forth by separation of powers involves both functions together. The one he describes as "primary" is the state function involving decision making and order giving, whereas the other function he describes as "secondary" is fulfilled by inferior official departments. The function of decision making and giving direction mentioned in Bluntschli's discourse as "primary" corresponds to politics, while the implementation of the decisions called as "secondary" corresponds to public administration. Expression of politics administration dichotomy in this way overlaps with Wilson's statements concerning this topic, confirming that his ideas originate from Bluntschli.

In his book, Wilson (1877, 210-211) also covers the views of Bluntschli, whom he acknowledges that his views on politics - administration dichotomy are based on and who, as he states, separates administration from politics and law. According to Wilson, Bluntschli believes that politics is for "great and universal" issues, whereas public administration is concerned with state activities related to "individual and small" things. Thus, politics is the activity of political statesmen; administration remains to be the activity of technical officials.

On the other hand, it is claimed that Wilson was influenced by German Richard T. Ely when he was doing his doctoral degree at Johns Hopkins University and he developed his views reading German theoreticians Hegel and Bluntschli. Wilson, who read extensively through Hegel and other German researchers from Hegel's philosophy, was the most influenced by Bluntschli (Pestritto 2007).

It is indicated that Richard T. Ely, who worked for Johns Hopkins University for 11 years, was the most prominent professor of Woodrow Wilson. Ely was a professor of political economy and a member of the German school of history; he saw the state as a living 
organism. Ely's approach to state can be traced to Hegel and Bluntschli (Thies and Pecquet 2010).

The German political theory which hinges on Hegel's views had a significant effect on the academic rhetoric of Johns Hopkins University. Within this framework, using the organic state theory, designating the state as the center, adopting the comparative approach of history as against methodological individualism and free market rhetoric was under consideration (Rosser 2010, 550).

Miewald (1984) asserts that, in Hegel's state theory, beurocracy remains as the protector of the general welfare from the conflicting personal interests. He also contends that this view was conveyed to America by Wilson. The writer finds Hegel's this view problematic and condemns Wilson for conveying this to America. Miewald was in the opinion that the liberty of bureaucracy was in question in Germany so that balance would be established against monarchy. Therefore, there was not any point in thinking that the same applied to America. According to Wilson, liberal bureaucracy requires not only the separation of administration from politics but also a much more fundamental approach, namely the consideration of administration power independently of the constitutional power (Pestritto 2005, 234).

The most prominent of the German theoreticians that had a profound effect on Wilson is Bluntschli, for he put greater stress on public administration and developed significant views. For Bluntschli, over-empowerment and politicization of bureaucracy was risky. Using the bureaucracy concept in a pejorative tone, the writer contends that bureaucracy is opposed to the objective fulfillment of societal needs and under the domination of technical knowledge and formal effects. For politics to be kept out of the scope of public administration, he also finds it sensible that high level public administrators should have certain political tendencies and should be assigned, and quit likewise, at the same time with the selection of politicians (Rosser 2011). It is interesting that this approach, which is still advocated today as it prevents the politicization of bureaucracy, was verbalized by Bluntschli in 1875.

Rosser (2010, 553), who investigated the extent to which Wilson was influenced by the German theoreticians, holds the view that it would be an unsustainable exaggeration to claim that his views were determined by them. Nevertheless, a comparison of Wilson's and Bluntschli's and Stein's articles clearly demonstrates that Wilson was profoundly interested in what the German writers wrote about public administration.

Since Wilson's article "The Study of Administration" was a first in America in terms of public administration, he was claimed to be the father of the discipline. Some researchers argue that he is not in that position, either because they see contemporary public administration as so divergent from his understanding or because the discipline's roots reach back much earlier (Pestritto 2005, 244).

Because Vivien discussed politics - administration dichotomy 28 years before Wilson's well-known article, the originator of this dichotomy is not Wilson. However, Wilson (1887, 210) states that he adopted this approach not from the French Vivien, but from the German Bluntschli. Though Wilson himself says so, some researchers interpreting his works claimed that the major contribution to the public administration discipline is the politics - 
administration dichotomy.

After all, Martin (1988) states in his article "The Fading Legacy of Woodrow Wilson" that most of the views concerning the emergence of public administration, in particular politics-administration dichotomy, attributed to Wilson are approaches put forth earlier in Europe. It will be deemed necessary to reevaluate the politics-administration dichotomy, which is already known and dealt with in European public administration studies, as to its importance for and the place in the discipline, for Wilson has merely quoted it.

\subsection{Accusation of a Wrong Translation}

Evidence exists supporting both that the European school was the source of public administration for the American school and that the two schools developed independently from each other. Raadschelders (1999, 286) contends that Germany, France, Italy, Netherlands and the Scandinavian countries developed a concept, the intellectual roots of which extend to philosophy, law, sociology, economy, political science, and history. In contrast to the American tradition, European public administration developed based on a strong state tradition. This situation rendered the European public administration connected to various disciplines, yet at the same time puzzled the scholars.

Development of the American and European public administrations differently was beyond doubt, but this difference was claimed to have arisen from Wilson's translating the German sources incorrectly. Martin (1988) highlights that Wilson's politics - administration dichotomy that hinges on such statements as "administration is out of the scope of politics and administrative issues are distinct from the political ones" is different in Europe. In Blutschli and older French literature, the principle of "administrators should be selected for their political and moral character" was valid. What is more, according to Martin, multi-diversification exists between legislation, execution, judgment and public administration and civil law in Europe. At this point, public administration has crystalized not as a discipline of business administration but as another means of expression of state's will.

Pestritto $(2005,233)$ also is of the opinion that Wilson sometimes misinterpreted the German sources. He contends that even Bluntschli himself did not establish as strict and extreme politics-administration dichotomy as Wilson did.

Martin (1988) maintains that Wilson accepted his mistake caused by mistranslating Bluntschli and other German sources three years after his 1887 article and the fact that "public administration questions are basically political questions" and that public administration was "a subject of civil law" in 1890.

In addition to Hegel, Bluntschli and Ely, Wilson also appraised such German and Australian scholars as Karl von Gareis, Otto von Sarwey and Georg Jellinek. Martin (1988, 633) states that Wilson's views on the characteristics of the field of public administration changed after reading the works of these researchers. He asserts that nobody regarded Wilson as the founder of the discipline until 1930's, but some developments that took place following this date stressed Wilson's dramatic impact on the management discipline, which brought Wilson to the forefront. 
Although Martin's findings are important, it should not go unnoticed that Wilson (1887, 210-211) explicitly stated that he had derived the politics-administration dichotomy from Bluntschli and that there is significant data supporting this in Bluntschli's foremost book The State Theory. Bluntschli's (2000, 409-410) characterizing politics as "primary" and government as "secondary" exhibits that he makes a distinction between politics and administration. Again it is evident that Bluntschli's relating the general state government to politics and activities more about details to administration has been the source of the famous dichotomy Wilson articulated.

Despite declaring that he based the politics - administration dichotomy on Bluntschli, Wilson never revealed that he took his view that public administration is closer to the discipline of business management from the European writers. Because both are management activities, the views supporting that public administration should be placed closer to business administration seem to belong to Wilson himself.

On the other hand, Wilson $(1887,202)$ advocated that public administration that emerged in Europe should be made compatible with USA, which observes a federal system, because of the central structures of European states. To him, public administration should be Americanized immediately. As can be seen here, Wilson is not much apt to transfer everything he has read to the USA literature. Therefore, the widespread criticism leveled at him which claimed that he had mistranslated the German sources and directly transferred them seems to be substantially unfair.

\section{Conclusion}

The present study intends to analyze the German, in particular Bluntschli's, influence on the emergence of public administration, laying down the German factors in origin contributing to the emergence of public administration.

When we define the divergence of the discipline of public administration from politics and law and its formation into one independent discipline as the emergence of public administration, then the formation and development of these concepts fall automatically into our scope of analysis. Although Wilson learned the differentiation of public administration and politics from Blutschli, it is the French Vivien who first proclaimed it. Nevertheless, Bluntschli advanced Vivien's thoughts, describing politics as primary and administration as secondary, and thus grounded the dichotomy.

Wilson also stated that he learned about the distinction between the discipline and civil law form Bluntschli. Bluntschli, however, asserts that the concept of separation of law from politics (and administration) was first proposed by Bonnin in 1812 in the rhetoric of "the prince should not judge". From then on, a most distinguished researcher Montesquieu, who separated legislation, execution and judgment from each other, proposed the separation of powers. Indeed, in the separation put forth by Bonnin and Montesquieu, administration and politics co-exists within "prince" or "execution power". When law and politics are separated, this would mean a separation from the administration that was part of politics in that period, thereof.

The German influence on the development of public administration can be explained from a 
few viewpoints:

- As an approach that emerged in Germany and served as a source to public administration, Cameralism is a primary German contribution.

- Stein, who is the first person to regard public administration as a "science", is accepted to be the founder of European public administration.

- Under the influence of the German school of history, Bluntschli suggested the "organic state" notion and advocated that different functions of the state should be carried out by different organs.

- Bluntschli grounded the politics - administration dichotomy and expressed politics in primary and administration in secondary consideration.

- The European centered politics - administration dichotomy was learned by Wilson from Bluntschli's work and transferred to the continent of America, forming the base of the USA public administration.

- Wilson, who is not considered to be the founder of public administration, but the founder of the American public administration, was influenced by the German school of history and political theorem at the Johns Hopkins University and adopted some of his opinions concerning the state at this very place.

The German influence could trigger the above mentioned significant effects in the emergence of the discipline of public administration. It could even be claimed that the German influence is greater than the French influence, which had achieved certain other firsts in this field. This can be explained by the fact that, in that period, the language of German was more influential and some data, which had been written in the language of French earlier, could make its way to the continent of America only when it was worded in the language of German.

\section{References}

Agbude, Godwyns Ade. 2011. "The Hegelian State and the Rise of the Tyranny of the Minority: The African Poitical Experiment", Journal of Sustainable Development in Africa, V.13, No.3. pp.114-131).

Backhaus, Jürgen, G. 2001. Constitutional Causes for Technological Leadership: Why Europe? Independent Institute Working Paper Number 39, August 2001; http://www.independent.org/pdf/working_papers/39_constitutional.pdf; 11.11.2011.

Bluntschli, J. Caspar. 2000. The Theory of The State, Batoche Books, Kitchener, 2000. (First published in German as "Lehre Vom Modernen Staat", First English version published in 1895).

Ferraro, A., and Ajenjo, N. 2007. A Positive Ethics for Public Administration: Altruism, Self-Interest and the Concept of the State; http://www.law.kuleuven.be/integriteit/ egpa/previous-egpa-conferences/madrid-2007/ferraro.pdf ; 13.11.2011.

Hobhouse, L., T. 1999. The Metaphysical Theory of the State: A Criticism, Batoche Books, Kitchener, Canada. 
Klinger, Andreas. 2005. "Veit Ludwig von Seckendorff's "F"ursten Stat" and the Duchy of Saxe-Gotha", European Journal of Law and Economics, 19: pp.249-266.

Link, Arthur S. 1968. "Woodrow Wilson and the Study of Administration", Proceedings of the American Philosophical Society, Vol. 112, No. 6, Dec. 9, 1968, pp.431-433.

Lodhi, M.S., and Mikulecky,P. 2010. "Knowledge Management Implementation in Public Services", International Conference on Communication and Management in Technological Innovation and Academic Globalization (COMATIA 10), Novemver 30-December 2 2010; http://www.wseas.us/e-library/conferences/2010/Tenerife/COMATIA/COMATIA-15.pdf; 13.11.2011.

Martin, Daniel W. 1988. "The Fading Legacy of Woodrow Wilson”, Public Administration Review, March - April 1988, pp. 631-636.

1987. "Deja Vu: French Antecedents of American Public Administration", Public Administration Review, V. 47, No. 4, July - August 1987.

Miewald, Robert. 1984. "The Origins of Wilson's Thought: The German Tradition and the Organic State." In Politics and Administration: Woodrow Wilson and the American Public Administration, ed. by Jack Rabin and James Bowman, 17-30. New York and Basel: Marcel Dekker; referred by Pestritto, Ronald J. 2005. Woodrow Wilson and the roots of modern liberalism, Rowman \& Littlefield Publisher Inc., p.229, and referred by Ferraro, A., and Ajenjo, N. 2007. A Positive Ethics for Public Administration: Altruism, Self-Interest and the Concept of the State; http://www.law.kuleuven.be/integriteit/ egpa/previous-egpa-conferences/madrid-2007/ferraro.pdf ; 13.11.2011.

Pestritto, Ronald J. 2007. "The Progressive Origins of The Administrative State: Wilson, Goodnow, And Landis", Social Philosophy \& Policy Foundation. Printed in the USA: pp. 16-54.

2005. Woodrow Wilson and the roots of modern liberalism, Rowman \&

Littlefield Publisher Inc.

Raadschelders, Jos C.N. 1999. A Coherent Framework for the Study of Public Administration, JPART, 9, 1999, 2 pp.281-303; http://jpart.oxfordjournals.org/; 08.11.2011.

Reinert, Erik S. 2005. "A Brief Introduction to Veit Ludwig von Seckendorff (1626-1692)”, European Journal of Law and Economics, 19: pp. 221-230.

1999. "The Role of The State in Economic Growth", Journal of Economic Studies, Vol. 26 No. 4/5, pp. 268-326.

Rosser, Christian. 2011. Johann Caspar Bluntschli's Organic Theory of State and Public Administration; http://www.irspm2010.com/workshops/papers/16_johanncaspar.pdf; 10.08.2011.

. 2010. "Woodrow Wilson's Administrative Thought and German Political Theory", Public Administration Review, July-August 2010, pp. 547-556.

Rutgers, Mark R. 2010a. “Theory and Scope of Public Administration: An Introduction to the 


\section{Macrothink}

Journal of Public Administration and Governance ISSN 2161-7104 2013, Vol. 3, No. 1

Study's Epistemology", Public Administration Review, Foundations of Public Administration Series; http://www.aspanet.org/scriptcontent/pdfs/FPA-Theory-Article.pdf; 11.08.2011.

. 2010b. "Chistiaan Von Wolff (1679-1754) as Cameralistic Philosopher", Prelude to Public Administration: Essential early European Authors on Administration (governors: M.R. Rutgers \& F. Sager), XIV IRSPM Conference. The Crisis: Challenges for Public Management, University of Berne, Centre of Competence for Public Management, 7-9 April 2010.

Seibel, Wolfgang. 2010. "Beyond Bureaucracy Public Administration and Non-Weberian Thought in Germany”, Public Administration Review V.70/5, September/October 2010 pp. 719-730.

Thornhill, C. 2006. "The Domain of Public Administration", Journal of Public Administration, Vol 41 no 4.1, December 2006, pp.793-806.

Thornhill C. and van Dijk G. 2010. "Public Administration Theory: Justification for Conceptualisation", Journal of Public Administration, Vol 45 no 1.1, June 2010, pp.95-110.

\section{Copyright Disclaimer}

Copyright reserved by the author.

This article is an open-access article distributed under the terms and conditions of the Creative Commons Attribution license (http://creativecommons.org/licenses/by/3.0/). 